\title{
THE FACTORS INFLUENCING THE PEDAGOGICAL ORIENTATIONS OF THE FINAL YEAR PHYSICAL SCIENCES PRE-SERVICE TEACHERS
}

\author{
Aviwe Sondlo, \& Umesh Ramnarain \\ University of Johannesburg (South Africa)
}

\begin{abstract}
Almost all pre-service teachers enter the profession of education with a strong belief that their efforts will make a positive contribution to society and the lives of individual learners. The statement above can be achieved or not achieved depending on different factors influencing pre-service teachers' pedagogies. The purpose of this study was to establish and explain factors influencing Physical Sciences pre-service teachers' pedagogical orientations. 'Orientation' refers to teachers' knowledge and beliefs about teaching sciences. There are various classifications of pedagogical orientations and they can be classified into Direct Didactic, Direct Active, Guided Inquiry and Open Inquiry. A qualitative approach was adopted to establish factors influencing the Physical Sciences pre-service teachers' pedagogical orientations. The data was collected through an existing instrument called the Pedagogy of Science Teaching Test (POSTT) and interviews. A POSTT was administered to final year undergraduate secondary school Physical Sciences pre-service teachers and is comprised of five items portraying an actual teaching scenario for a particular Physical Sciences topic. When responding to the POSTT, pre-service teachers were requested to select the most appropriate and the most inappropriate pedagogical orientation from the four options given and justify their selected option. Eight Physical Sciences pre-service teachers were purposefully selected for interviews. The interviews were part of the study to give pre-service teachers a chance to elaborate on their POSTT responses. The findings of this study revealed that the Physical Sciences preservice teachers' pedagogical orientations were influenced by the following factors: time constraints, availability of resources, and curriculum goals to mention a few.
\end{abstract}

Keywords: Pedagogical content knowledge, pedagogical orientations, inquiry-base learning.

\section{Introduction}

After 1994 when South Africa received democracy, the educational system experienced several changes that were part of redressing the wrongdoings of the previous government and promoting quality education to all citizens. The school curriculum was changed to make it relevant, significant, address skill shortages, promote knowledge and mirror education that reflects the needs of all South Africans (Mouton, Louw, \& Strydom, 2012). For the past 27 years, several school curriculums were introduced and changed until recently (2011) were a Curriculum and Assessment Policy Statement (CAPS) was introduced at school. CAPS is significantly different from the previous curriculums, where subject boundaries are no longer vague compare to others and it has week-by-week teaching plans. However, there is less room for teacher creativity and possibly even more constricted space for the integration with other teaching methods because the CAPS give detailed guidance to teachers on what they should teach and how to assess learners (Umalusi, 2014). Even though the CAPS emphasis is on inquiry-based learning (IBL) as a teaching approach for science subjects, it still doesn't give teachers room to employ IBL. The emphasis on IBL is reflected in specific aim two (Department of Basic Education, 2011) and the CAPS aims are in line with the trends in science education worldwide which promote inquiry-based instructions (Mokiwa, 2014). However, the pre-service teachers experienced different factors/challenges that forbids them to implement IBL activities in the science classroom. This paper defines inquiry-based learning as a teaching strategy where learners are given a chance to grapple with data, using evidence and logic to make sense of some event or phenomena in a social, collaborative environment (National Research Council, 1996; 2000; NRC, 2012). The NRC (1996) refers to an inquiry as activities where students develop knowledge and understanding of scientific ideas and understanding of how scientists study the natural world in their everyday lives. The inquiry stems from how people learn, where learning stems from natural curiosity which will make learners develop curiosity and have an interest in science at a young age (Mupira \& Ramnarain, 2018). This study aimed to explore factors influencing the Physical 
Sciences pre-service teachers' pedagogical orientations towards their classroom teaching. To achieve the aim, the following research question was conceptualised:

i. What factors influence the pedagogical orientations of Physical Science pre-service teachers?

To understand the factors influencing Physical Sciences pre-service teachers' pedagogical orientations, we administered a questionnaire (POSTT) to Physical Sciences final year undergraduate preservice teachers (Cobern et al., 2014).

\section{Factors influencing teachers at school}

The research shows that pre-service teachers in their early years of teaching, their level of understanding science is like that of their learners (Mavhunga, 2014). However, as they gain experience their awareness of science changes significantly, moving from reasoning as learners or how they were taught science at school, to become conscious of how the subject is transformed for learner understating (Angell, Ryder, \& Scott, 2005). Students' secondary school education background, a limited number of science teachers, large numbers of under-qualified or non-qualified Physical Science teachers and over-crowded classes were some of the factors (Makgatho \& Mji, 2006). Mokiwa (2014) asserts that teachers think that learners find it challenging to learn through inquiry because they get distracted. Other factors that prevent teachers to adopt a learner-centred approach; Most of the teachers were not exposed to this method early as either learner at school or as pre-service teachers at university. Lack of resources, large classes and lack of exposure to inquiry-based learning are other factors that hinder the implementation of IBL in some of the schools (Nyirenda, 2019; Ramnarain et al., 2014). These are some of the factors that pose a significant challenge to teachers at school as they try to shift from traditional instruction to inquiry-based approaches (Ladachartm, 2019).

\section{Theoretical framework}

Pedagogical Content Knowledge (PCK) underpins the study as a theoretical framework. PCK is a blend of pedagogical and content knowledge that formulates the transformation of the two mentioned knowledge into the most powerful, teachable forms to express the subject and make it comprehensible for learners understanding (Shulman, 1987). Within PCK, Grossman (1990); Magnusson, Krajcik, and Borko (1999) extended the PCK model by adding a key construct in teaching and referred to this as teaching orientations. Cobern et al. (2014) were interested in the teaching of science content and they developed an assessment device that borrowed from the concepts of PCK, teaching orientations and Ausubel's theory of meaningful learning (Ausubel, Novak, \& Hanesian, 1986) to conceptualised the idea of pedagogical orientation. The construct 'orientation' refers to teachers' knowledge and beliefs about the purposes and goals of teaching science at a particular grade level (Magnusson et al., 1999). Anderson and Smith (1987) referred to teaching orientations as various approaches to teaching science and general patterns of teacher's behaviours and thoughts to promote learner's chances of comprehending science concepts. Magnusson et al. (1999) assert that teaching orientations are an essential factor shaping teacher's PCK. Orientations shape teacher's knowledge of science curricula and knowledge of learner understanding which includes learner's prior knowledge (Gess-Newsome, 2015). Therefore, this study used the four pedagogical orientations proposed by Cobern et al. (2014) and they are:

- Direct Didactic- a teacher, presents and explains the science concept directly to the students and illustrates it with examples. Students apply this knowledge to questions and problems. There are no or few student practical activities in this method.

- Direct Active- similarly entails direct teacher exposition, but this is followed by a student activity based on the presented science content, for example, hands-on practical verification of a law.

- Guided Inquiry- a teacher plans an activity where students explore a phenomenon, from this, the teacher guides them to develop the desired science concept.

- Open Inquiry orientation- students explore a phenomenon on their own, devising ways of doing so, minimally guided, after which they report what they did and found.

The first two orientations are direct approaches, these are referred to as teacher-centred and the last two orientations are inquiry approaches and are more learner-centred. These four orientations were used to explore pre-service teacher's pedagogical orientations. 


\section{The context of the study}

The starting point of this study was to establish the pedagogical orientations of pre-service teachers, this was done by administering a questionnaire called POSTT and each POSTT had five teaching scenarios where pre-service teachers were required to envisage their teaching approaches i.e. how they were going to teach each lesson. The goal of each item was to elicit teacher's orientations towards teaching science and encourage the pre-service teacher to visualise himself or herself teaching that particular concept, playing the role of a decision-maker and respond as if he/she was going to teach that lesson. They were required to select the most appropriate pedagogical orientation from the four options given and justify their choices. The POSTT quantitative results were in descending order, were: Guided Inquiry (34\%), Open Inquiry (24\%), Direct Active (24\%) and Direct Didactic (18\%) (Sondlo \& Ramnarain, 2019). Therefore, Guided Inquiry was the most preferred pedagogical orientation among this cohort of pre-service teachers (Sondlo \& Ramnarain, 2019). Following the quantitative results, the researchers were then interested to find out what were factors influencing these Physical Sciences pre-service teachers to select a particular choice instead of the other three choices. The pre-service teachers' reasons/justifications will be presented in this paper as factors that influenced the Physical Sciences pre-service teachers' pedagogical orientations. The quantitative results assisted the authors to understand the factors that influenced the pre-service teachers to select a particular orientation.

\section{Research design}

A qualitative approach was used where a questionnaire item was administered to all Physical Sciences final year students at a South African university and interviews followed. The pre-service teachers were required to select the most appropriate pedagogical orientation from the four options given and justify their choices. Then eight Physical Science pre-service teachers were selected for interviews. The selection was based on their responses/pedagogical orientation and based on the context of the school they were teaching at during their teaching practicum. Therefore, the provided reasons helped the researchers to understand the factors influencing their orientations. The qualitative data from the POSTT and semi-structured interviews were analysed using standard methods where the data was first transcribed, coded and analysed. The deductive and inductive reasoning approaches were used to establish factors influencing the Physical Science pre-service teachers' pedagogical orientations where themes were generated following Saldana (2009) methods. When generating thematises, in-vivo coding, as well as descriptive coding were used. In-vivo coding is when the coder takes the exact words spoken by a participant, while descriptive coding is used when summarising what is said in a passage by one word or a short phrase (Saldana, 2009).

\section{Results}

In the previous paper by Sondlo et al. (2019), it emerged that the Physical Sciences pre-service teachers exhibited a preference for learner-centred orientation, which was a guided inquiry pedagogical orientation. However, when analysing the pre-service teachers' qualitative responses it emerges that most of them selected an inquiry orientation but their reasons support a traditional method orientation which can be Direct Didactic or Direct Active orientation. Therefore, this paper is curious to understand factors that influenced them to select a guided inquiry orientation which is equivalent to an inquiry based learning approach on the POSTT but prefer a teacher-centred orientation approach. The factors influencing the Physical Sciences pre-service teachers are presented below.

\subsection{Theme one: Environmental factors such as class size, resources and time constraints at school influenced the preferred Physical Sciences pre-service teachers}

Lack of resources, large class size and insufficient teaching time were factors that influenced Physical Sciences pre-service teachers in their preference for a teacher-centred orientation.

6.1.1. Lack of resources and a large number of learners per class. The availability of resources and large classes emerged as factors influencing the pre-service teachers' pedagogical orientations since these factors impact the autonomy of the pre-service teachers to adopt a learner-centred teaching approach. One of the participants, Mr Motsapi mentioned that at his school there was a laboratory but there were few resources to use.

Taking the resources of the school, the school has a laboratory but it does not have the most resources, so I ended up doing a demonstration. This strategy may seem teacher-centred at first but there is learner involvement and discovery learning. 
Mr Motsapi agrees that at a school where he was placed during teaching practicum there were few resources and he was aware that demonstrations tend to be teacher-centred instead of being learnercentred. The second pre-service teacher (Ms Faltein):

In my school, they were no lab and there were many students in one class, so, I had to use home materials when teaching other concepts.

She further elaborates that even though there was no laboratory at her former school, she was willing to go beyond, however, her lessons were teacher-centred since she was the person doing all the work while learners were observing.

Therefore, on paper, the preservice teachers were willing to adopt inquiry, however, factors such as resources, and large numbers of learners in one class had an impact on them to revert into traditional methods.

6.1.2. Insufficient teaching time. Lack of time was another factor that led pre-service teachers to opt for a teacher-centred approach towards their teaching.

At the secondary school level, timetabling is the responsibility of the School Management Team (SMT). However, they get guidance from the CAPS document where Physical Sciences as a subject is allocated four hours per week and the school had the prerogative to distribute time the way they want. In most schools, Physical Sciences lessons are less than 1-hour. Some schools prefer to have at least one double period per week and the remaining time is divided into single periods according to the school time table. The four hours per week was for both theory and laboratory experiments. Therefore, time was a factor to some Physical Sciences pre-service teachers. one of the pre-service teachers Ms Sibeko explained that insufficient time to teach was always a factor.

Most of the inquiry lessons are time-consuming as other learners may not find the correct equipment's or resources to experiment on their own and it might seem impossible to find another way of measuring the volume of objects without measuring the objects themselves.

Ms Sibeko further pointed out that CAPS was limiting her creativity and this was the reason she pointed out the impact of time in her teaching. Mr Jacobs also shared similar sentiments as Ms Sibeko where he argued that time to teach Physical Sciences was not enough.

The time given for Physical Sciences classes is not enough to follow the learner-centred approach in class unless if it was made a practical where they will have to spend the time in the laboratory doing this experiment.

Ms Sibeko and Mr Jacobs claim that insufficient time for Physical Sciences lessons was a factor since the four hours per week were for both content/theory and practical work.

\subsection{Theme two: Curriculum goals specified in the CAPS document influenced the Physical Sciences pre-service teachers to select Inquiry pedagogical orientations}

The goals of the curriculum influenced some of the pre-service teachers' preference for learner-centred pedagogical orientations. One of the CAPS goals is to promote inquiry-based learning (IBL) as a teaching approach for science subjects and this is reflected in specific aim two. CAPS encouraged an active and critical approach to learning and discourage rote learning. Quite a number of the Physical Sciences pre-service preferred orientation that were aligned to the goals of the curriculum which led them to select learner-centred pedagogical orientations. Mr Motsapi in one of the items selected an Open Inquiry orientation since it was based on inquiry approaches.

I selected option B because in grade 9 Natural Sciences, the learners studied acids and bases and also common examples of acids and bases. Therefore, I will let them do practical to improves the learners' manipulative and investigative skills (and the Physical Sciences Specific Aim 2 'doing Science'.

Ms Sibeko was using CAPS to determine skills that were important to develop the learners by the end of the lesson or topic.

This approach makes learners develop creative and critical thinking skills which are required by the curriculum.

Even Mr Matoto was in favour of inquiry orientation since they were in line with the skills that were listed in the CAPS document.

This option also addresses the specific aim 1 of doing science whereby the learners are allowed to be hands-on and do the work themselves.

Therefore, the curriculum goals stipulated in the CAPS document assisted some of the Physical Sciences pre-service teachers to favour a learner-centred teaching orientation that promotes IBL and even though curriculum specifications listed above limit them to adopt IBL or learner-centred teaching approaches. 


\section{Discussions and conclusion}

To respond to the research question 'what are the factors influencing the pedagogical orientations of the Physical Sciences pre-service teachers?'. The findings from this paper brought to light that the Physical Science pre-service teacher's pedagogical orientations were influenced by factors such as the number of learners, time constraints, availability of resources and curriculum goals. The results of this study were similar to Nyirenda (2019); Ramnarain, Schuster (2014); Makgatho et al. (2006) which shows that lack of resources, large classes and lack of exposure to inquiry-based learning hinders the implementation of IBL. Nyirenda (2019) study also show that curriculum and time were dominant factors influencing the Zambian science pre-service teachers. The findings from this paper are similar to Ramnarain et al. (2014: 2016) that context influence teacher's orientations and teaching orientations are like a map guiding teacher's decisions making process when preparing a lesson (Magnusson et al., 1999).

\section{References}

Askew, M., Venkat, H., Rollnick, M., \& Loughran, J. (Eds.), (2014). Exploring Content Knowledge for Teaching Science and Mathematics: Windows into teacher thinking. Abington, UK: Routledge.

Ausubel, D. P., Novak, J. D., \& Hanesian, H. (1986). Educational Psychology: A Cognitive View (2 ${ }^{\text {nd }}$ ed.). New York: Werbel \& Peck.

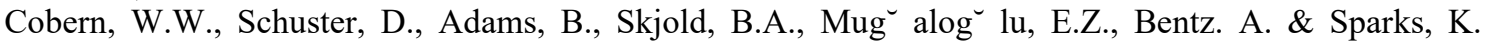
(2014). Science Teaching Tests: Formative assessments of science teaching orientations. International Journal of Science Education, 36(13), 2265-2288.

Department of Basic Education, Republic of South Africa. (2011). Curriculum and Assessment Policy Statement (CAPS): Physical Sciences. Final draft. Pretoria: Government Printer.

Gess-Newsome J. \& N. G. Lederman (Eds.), (1999). Examining pedagogical content knowledge (pp. 95-132). Dordrecht, the Netherlands: Kluwer.

Koehler, J. (Ed.), (1987). The educator's handbook: A research perspective (pp. 84-111). New York: Longman.

Ladachart, L. (2019). Thai First-Year Preservice Science Teachers' Orientations Toward Teaching Science. Asia-Pacific Edu Res.

Makgatho, M. \& Mji, A. (2006). Factors Associated with High School Learners' Poor performance: A spotlight on mathematics and physical science. South African Journal of Education. 26(2), 253-266.

Mokiwa, H., O. (2014). Exploring the Teaching of Physical Science through Inquiry. International Journal of Edu Sci, 7(1): 21-27.

Mouton, N., Louw, G. P., \& Strydom, G. L. (2012). A Historical Analysis of the Post-Apartheid Dispensation Education in South Africa (1994-2011). International Business \& Economics Research Journal, 11 (11), 1211-1222.

Mupira P. \& Ramnarain U. (2018). The effect of inquiry-based learning on the achievement goal-orientation of grade 10 physical sciences learners at township schools in South Africa. Journal of Research in Science Teaching, 55(6), 810-825.

National Research Council [NRC]. (1996). National science education standards. Washington, DC: National Academy Press.

Nyirenda, E. (2019). Zambian Secondary School Pre-Service Science Teachers Pedagogical Orientations and Beliefs about Science Teaching. Unpublished Doctoral thesis, Southern Illinois University Carbondale.

Ramnarain, U., \& Schuster, D. (2014). The Pedagogical Orientations of South African Physical Sciences Teachers towards Inquiry or Direct Instructional Approaches. Research in Science Education, 44(4), 627-650.

Saldana. (2009). An Introduction to Codes and Coding. Retrieved on 23 Feb 2019. From: http://www.sagepub.com/sites/default/files/upm-binaries/24614_01_Saldana_Ch_01.pdf

Shulman, L. (1986). Those who understand: Knowledge growth in teaching. Educational Researcher, 15(2), 4-14.

Sondlo, A., \& Ramnarain, U. (2019, June). Exploring the South African Physical Sciences Pre-Service Teachers Pedagogical Orientations. International Conference on Education and New Developments (END 2019). Porto, Portugal, 22 - 24 June 2019. 